\title{
Acute Hemorrhagic Encephalitis Related to COVID-19
}

\author{
Alan Chalil, MD, MSc, Carmen S. Baker, MD, Robert B. Johnston, MD, Caroline Just, MD, FRCPC, \\ Derek B. Debicki, MD, PhD, FRCPC, Michael S. Mayich, MD, FRCPC, Karen J. Bosma, MD, FRCPC, \\ and David A. Steven, MD, MPH, FRCSC, FACS
}

\author{
Correspondence \\ Dr. Steven \\ david.steven@Ihsc.on.ca
}

Neurology: Clinical Practice April 2021 vol. 11 no. 2 e147-e151 doi:10.1212/CPJ.0000000000000900

\section{Abstract}

\section{Purpose of Review}

The novel severe acute respiratory syndrome coronavirus 2 (SARSCoV-2) is the most critical public health challenge in recent history. In this report, we present a case of suspected acute hemorrhagic encephalitis with bilateral intracranial hemorrhages associated with coronavirus disease 2019 (COVID-19) infection.

\section{Recent Findings}

A 48-year-old female COVID-19-positive patient developed acute changes in her neurologic status. A head CT with CT angiography demonstrated extensive bilateral parietal and occipital intraparenchymal hemorrhage with intraventricular extension and acute hydrocephalus. The patient was treated with an external ventricular drain, and a CSF sample was tested for SARS-CoV-2 but was found to be negative.

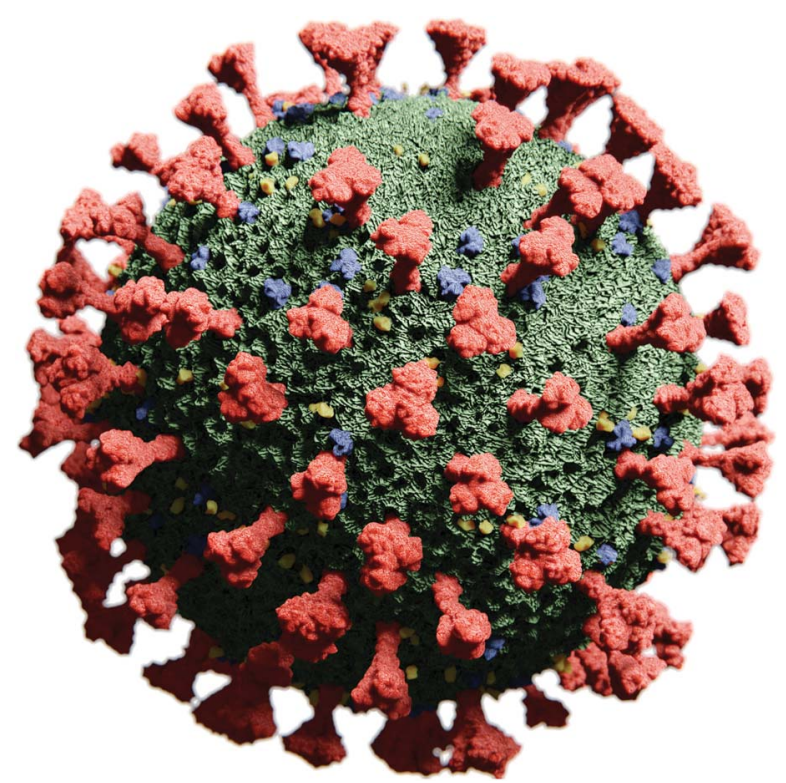

\section{Summary}

The underlying mechanism for developing acute hemorrhagic encephalitis in viral illnesses may be autoimmune in nature and warrants further investigation. The initial neurologic presentation of COVID-19-related hemorrhagic encephalitis is altered level of consciousness, which may prompt further neurologic examination and imaging to exclude this feature.

Coronavirus disease 2019 (COVID-19) is a newly identified respiratory illness caused by a novel coronavirus, SARS-CoV-2. ${ }^{1}$ Since the first reported cases in December 2019, COVID-19 has grown into a global pandemic and has become one of the most critical public health challenges in modern history. ${ }^{1}$ Although current data suggest that as many as $93 \%$ of infected individuals may be asymptomatic, ${ }^{2}$ symptoms generally include fever, dry cough, sore throat, and diarrhea. Serious complications can arise from COVID-19 infection, including pneumonia, acute respiratory distress syndrome, multiorgan failure, and death. ${ }^{3}$

There are relatively limited data addressing the neurologic complications of COVID-19., The most robust study to date suggests that approximately $1 / 3$ of patients can have neurologic complications that can vary from benign (headache and dizziness) to altered mental status and seizures. ${ }^{5}$ In addition, there have been reports of encephalopathy in elderly patients $^{4}$ and 1 case report of hemorrhagic necrotizing encephalopathy related to COVID-19. ${ }^{6}$

\section{MORE ONLINE}

\section{COVID-19 Resources}

For the latest articles, invited commentaries, and blogs from physicians around the world NPub.org/COVID19

\footnotetext{
Department of Clinical Neurological Sciences (AC, RBJ, CJ, DBD, DAS), Schulich School of Medicine and Dentistry, Western University; Department of Physical Medicine and Rehabilitation (CSB), Schulich School of Medicine and Dentistry, Western University; Department of Medical Imaging (MSM), Schulich School of Medicine and Dentistry, Western University; Department of Medicine (KJB), Schulich School of Medicine and Dentistry, Western University; and Department of Epidemiology and Biostatistics (DAS), Schulich School of Medicine and Dentistry, Western University, London, Ontario, Canada.

Funding information and disclosures are provided at the end of the article. Full disclosure form information provided by the authors is available with the full text of this article at Neurology.org/cp.
} 
In this current report, we present the unique case of a 48year-old patient who developed acute hemorrhagic encephalitis with bilateral intracranial hemorrhage associated with COVID-19 infection.

\section{Case Presentation}

A 48-year-old previously healthy woman was admitted to our institution after experiencing 2 weeks of myalgia, dry cough, shortness of breath, and fever. On presentation, the patient was hypoxic, prompting intubation and admission to the intensive care unit where COVID-19 status was confirmed to be positive by SARS-CoV-2 PCR testing. Pulmonary CT demonstrated characteristic features including extensive bilateral ground glass opacity with areas of consolidation and interlobular septal thickening (figure 1). The patient received hydroxychloroquine (oral, 2 doses of $400 \mathrm{mg}$ and 5 doses of $200 \mathrm{mg}$ ) and 2 doses of tocilizumab. Hydroxychloroquine was stopped due to development of supraventricular tachycardia and prolonged QT interval on electrocardiogram. Bloodwork demonstrated markedly elevated $\mathrm{D}$-dimers with severe hypoxemia, and she was started on IV heparin infusion on postadmission day 10 , with only a single partial thromboplastin time outside of therapeutic range, which was promptly corrected. Bloodwork also demonstrated elevated ferritin at $920 \mu \mathrm{g} / \mathrm{L}$ and a mildly elevated CRP of $11.7 \mathrm{mg} / \mathrm{L}$. On postadmission day 15 , she was found to have equal and nonreactive pupils bilaterally with

Figure 1 Unenhanced Axial CT of the Thorax

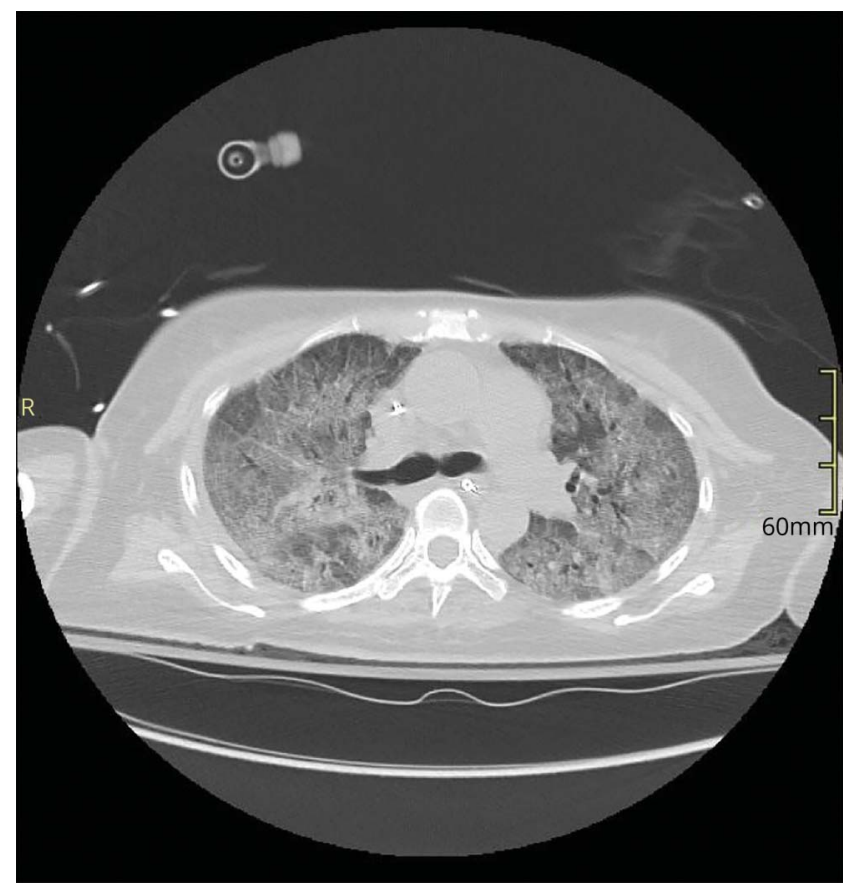

An axial image through the level of the carina demonstrating bilaterally extensive ground-glass opacity with early consolidation and interlobular septal thickening. absent cough, gag, and corneal reflexes. A head CT with CT angiography demonstrated extensive bilateral parietal and occipital intraparenchymal hemorrhage with intraventricular extension and acute hydrocephalus (figure 2). There was no evidence of an underlying vascular lesion including venous thrombus or aneurysm. Heparin infusion was stopped immediately and reversed with protamine sulfate. Hyperosmolar therapy was initiated, and an external ventricular drain (EVD) was inserted for intracranial pressure management. Post-EVD insertion, the patient's brainstem reflexes returned, and she was demonstrating extensor posturing to central pain. A repeat CT scan 48 hours later demonstrated stability of the hemorrhages. MRI failed to demonstrate any underlying ischemia but showed cortical gadolinium enhancement with hyperintense T2 and fluidattenuated inversion recovery signal surrounding the hemorrhages, in keeping with vasogenic edema previously seen on CT (figure 3). PCR testing on CSF taken from the EVD within 24 hours of insertion was negative for SARS-CoV-2 (table). The CSF had $76 \times 10^{\wedge} 6 / \mathrm{L}$ nucleated cells $(65 \%$ neutrophils) in the presence of $33,000 \times 10^{\wedge} 6 / \mathrm{L}$ erythrocytes. Of note, the CSF immunoglobulin $\mathrm{G}(\mathrm{IgG})$ ratio was 0.35 with an IgG index of 1.05. A digital subtraction angiogram was not performed due to the patient's COVID-19 status and unstable condition. The patient was eventually extubated and is currently recovering with severe neurologic deficits. She is currently undergoing rehabilitation.

\section{Discussion}

One of the biggest challenges facing physicians and health care workers addressing the COVID-19 pandemic is the wide variability in presenting features, which range from completely asymptomatic individuals to severe acute respiratory distress requiring mechanical ventilation, unconventional treatments, and extensive life-saving measures. ${ }^{3}$ Features attributable to CNS involvement by COVID-19 are rare but were described in an early population-based study from Wuhan.

We present a suspected case of acute hemorrhagic encephalitis in a previously healthy 48-year-old COVID-19-positive patient. Acute hemorrhagic encephalitis is believed to be a

Figure 2 Unenhanced CT of the Head

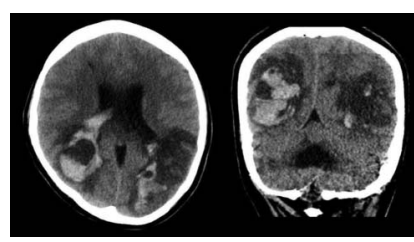

Axial and coronal reformatted unenhanced CT images demonstrating extensive intraparenchymal hemorrhage in bilateral parietal and occipital lobes with intraventricular extension and acute hydrocephalus. 


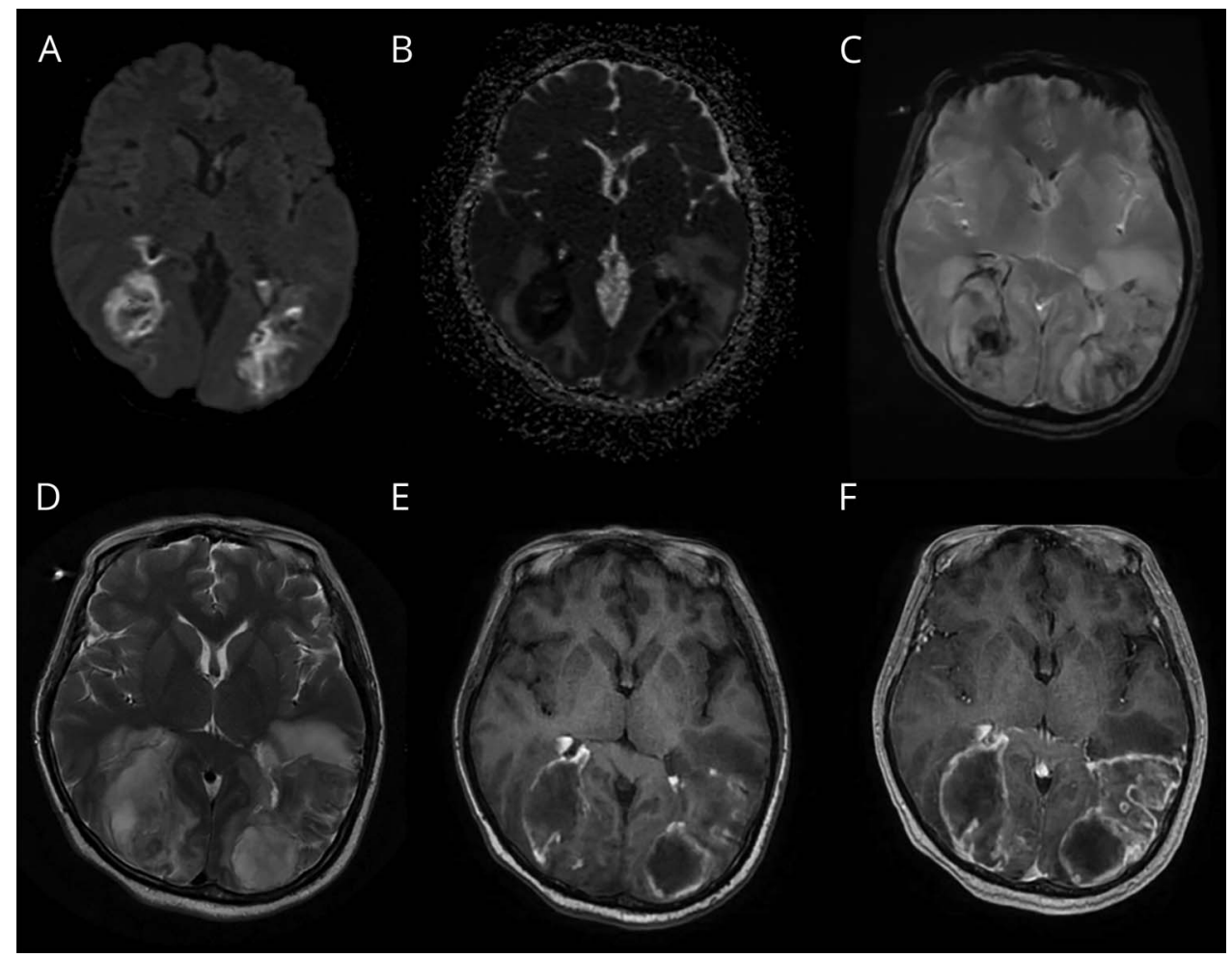

DWI-ADC images (A and B) demonstrating diffusion restriction limited to areas of hemorrhage demonstrated on MPGR images (C). T2 images (D) demonstrate extensive associated edema. Postcontrast T1 images (F) demonstrate extensive enhancement in addition to intrinsic T1 related to blood products on precontrast images $(E)$, including involvement of the cortex. $A D C=$ apparent diffusion coefficient; $\mathrm{DWI}=$ diffusion-weighted imaging; MPGR = multiplanar gradient recalled acquisition.

postinfectious process that is a severe variant of acute disseminated encephalomyelitis and has been described in other viral respiratory infections such as $\mathrm{H} 1 \mathrm{~N} 1$ Influenza. Another similar entity is acute necrotizing hemorrhagic encephalopathy, although lack of thalamic involvement in our case makes this less likely. ${ }^{7-9}$

The first case of acute hemorrhagic encephalitis associated with COVID-19 was reported in Detroit, Michigan, in March $2020 .^{6}$ In that case, thalamic involvement suggested that the underlying diagnosis was acute hemorrhagic necrotizing encephalopathy. The patients are demographically similar; however, the cases differ in location and extent of intracranial features (table). It is suspected that the large bilateral intraparenchymal hemorrhage with intraventricular extension was related to the presence of full anticoagulation. Heparin infusion was initiated because the patient's elevated D-dimer; at that time, anticoagulation was deemed the appropriate treatment.

Imaging was completed to determine the underlying etiology of the bilateral parietal-occipital intraparenchymal hemorrhage. An MRI and a CT angiogram (timed to optimize assessment of arterial and venous phases) demonstrated patency of arterial and venous structures. There was no evidence of vasculopathy, aneurysm (including peripheral mycotic lesions), or vascular malformation. The pattern of edema and hemorrhage was inconsistent with watershed infarct. Posterior reversible encephalopathy syndrome (PRES) was considered unlikely due to the extensive hemorrhage and progressive nature of the findings despite supportive care. It is noted that the patient was briefly treated with tocilizumab, for which there is 1 case report of associated PRES. ${ }^{10}$ No other precipitating factors for PRES were identified. Small vessel vasculitis was not suspected based on the available imaging. A digital subtraction angiogram would have definitively ruled out small vessel vasculitis; however, given the patient's diagnosis and unstable condition, this procedure could not be performed.

Having ruled out other differential diagnoses and with the absence of virus in the CSF, the presumed diagnosis of exclusion was one of acute hemorrhagic encephalitis. There are many proposed mechanisms by which SARS-CoV-2 virus can cause nervous system injury, including neural expression of angiotensin-converting enzyme 2 receptors, retrograde neuronal transport, vascular dissemination, systemic or focal hypoxic injury, or as a consequence of cytokine storm. ${ }^{5,11,12}$ Acute hemorrhagic encephalitis may be related to an autoimmune process with an inflammatory response leading to perivascular demyelination and associated edema, hemorrhage, and necrosis. ${ }^{13}$ Support for this comes from the finding that CSF for viral PCR is often negative, as it was for this patient, which suggests that the process is not due to direct viral infiltration of brain parenchyma. ${ }^{13,14}$ Similarly, the presence of an elevated IgG 
Table Comparison of Case Study Patient Demographics Presented Here and in the Literature ${ }^{4,6}$

\begin{tabular}{|c|c|c|c|}
\hline & Current study & Poyiadji et al. & Filatov et al. \\
\hline Diagnosis & $\begin{array}{l}\text { Acute hemorrhagic } \\
\text { leukoencephalitis }\end{array}$ & $\begin{array}{l}\text { Hemorrhagic } \\
\text { encephalopathy }\end{array}$ & $\begin{array}{l}\text { Encephalopathy } \\
\text { (nonhemorrhagic) }\end{array}$ \\
\hline Age, y & Late 40s & $50 \mathrm{~s}$ & 72 \\
\hline Sex & Female & Female & Male \\
\hline Comorbidities & None & Unknown & $\begin{array}{l}\text { Atrial fibrillation } \\
\text { Cardioembolic stroke } \\
\text { Parkinson disease } \\
\text { COPD } \\
\text { Recent cellulitis }\end{array}$ \\
\hline Presumed source & Community & Travel & Travel \\
\hline $\begin{array}{l}\text { Presenting } \\
\text { symptoms }\end{array}$ & Shortness of breath & $\begin{array}{l}\text { Fever, cough, and altered } \\
\text { mental status }\end{array}$ & Fever and cough \\
\hline $\begin{array}{l}\text { Neurologic } \\
\text { symptoms }\end{array}$ & $\begin{array}{l}\text { Altered mental status (intubated), then } \\
\text { weak cough, poor corneal reflexes }\end{array}$ & Altered mental status & Decreased level of consciousness \\
\hline Timeline & $\begin{array}{l}2 \text { weeks after initial presentation; } 5 \text { days } \\
\text { after therapeutic heparin infusion initiated }\end{array}$ & Unknown & Unknown \\
\hline Initial CT & $\begin{array}{l}\text { Bilateral parieto-occipital hematoma and } \\
\text { extensive edema causing hydrocephalus }\end{array}$ & $\begin{array}{l}\text { Hypoattenuation within bilateral medial } \\
\text { thalami }\end{array}$ & $\begin{array}{l}\text { Nil acute encephalomalacia } \\
\text { (prior stroke) }\end{array}$ \\
\hline MRI & $\begin{array}{l}\text { No watershed infarct } \\
\text { Extensive enhancement and cortical } \\
\text { involvement in the hemorrhage area. }\end{array}$ & $\begin{array}{l}\text { Hemorrhagic rim-enhancing lesions within } \\
\text { bilateral thalami, medial temporal lobes, } \\
\text { and subinsular regions. }\end{array}$ & \\
\hline EEG & $\begin{array}{l}\text { Mild diffuse slowing characteristic of } \\
\text { encephalopathy, rare left temporal } \\
\text { epileptiform discharges }\end{array}$ & Unknown & $\begin{array}{l}\text { Diffuse slowing and sharply contoured } \\
\text { waves, characteristic of encephalopathy }\end{array}$ \\
\hline CSF analysis & $\begin{array}{l}\text { Negative for COVID-19 } \\
\text { Erythrocytes } 33,000 \times 10^{\wedge} 6 / \mathrm{L} \\
\text { IgG ratio } 0.35(0-0.23) \\
\text { IgG index } 1.05(0.25-0.85) \\
\text { Negative for VZV, HSV, and ENV }\end{array}$ & Traumatic-negative for infection & $\begin{array}{l}\text { Negative for infection (WBC } 4 \text { [count/mm³), } \\
\text { protein } 68 \mathrm{mg} / \mathrm{dl} \text {, and glucose } 75 \mathrm{mg} / \mathrm{dl} \text { ) }\end{array}$ \\
\hline Outcome & $\begin{array}{l}\text { Extubated with significant neurologic } \\
\text { deficits. Currently receiving } \\
\text { rehabilitation. }\end{array}$ & Unknown & $\begin{array}{l}\text { In critical condition in the intensive care } \\
\text { unit. }\end{array}$ \\
\hline
\end{tabular}

Abbreviations: EBV = Epstein-Barr virus; HSV = herpes simplex virus; VZV = varicella zoster virus; $\mathrm{WBC}=$ white blood count.

index with elevated CSF IgG ratio ${ }^{8}$ and a neutrophil predominant CSF leukocyte count ${ }^{7}$ is in keeping with an inflammatory process rather than a direct viral effect. However, an inflammatory process could only be confirmed with biopsy, which the patient did not undergo. Furthermore, it is also possible that the CSF neutrophilia was influenced by the presence of intraventricular hemorrhage. Although treatment strategies directed toward mitigating the inflammatory response have been used in acute hemorrhagic encephalitis, such as IV immunoglobulin, plasma exchange, or corticosteroids, the outcomes in the few reported adult cases suggest that prognosis is poor. ${ }^{14}$

The extensive hemorrhage was most likely related to the use of systemic anticoagulation. There is ongoing debate regarding the appropriate management of patients with COVID-19 who display features consistent with a prothrombotic state, with or without evidence of tissue thrombosis. The present case highlights the need for ongoing neurologic surveillance and the clear risk of neurologic complications in patients with COVID19. This is particularly true when anticoagulation is deemed the appropriate treatment strategy and even more so when clinical assessments are limited because of the use of sedation and paralytics to assist in ventilation.

We present a case of a previously healthy 48-year-old woman with COVID-19 who developed acute hemorrhagic encephalitis, a complication which has been rarely described to this point. The underlying mechanism for developing such complication is believed to be autoimmune or paraviral in nature and warrants further investigation. At present, it appears that the initial neurologic presentation of COVID-19-related hemorrhagic encephalitis is altered level of consciousness, which may prompt further neurologic examination and imaging to exclude this feature. The observed intraparenchymal hemorrhage was most likely 
exacerbated by systemic anticoagulation and highlights the potential for neurologic complications in these severely ill patients with COVID-19. These findings may inform risk assessment and medical management in these patients, particularly as it pertains to the use of systemic anticoagulation and to the importance of ongoing neurologic assessment.

\section{Study Funding}

No targeted funding reported.

\section{Disclosure}

The authors report no disclosures relevant to the manuscript. Full disclosure form information provided by the authors is available with the full text of this article at Neurology.org/cp.

\section{Publication History}

Received by Neurology: Clinical Practice April 28, 2020. Accepted in final form June 26, 2020.

\section{TAKE-HOME POINTS}

$\rightarrow$ Features attributable to CNS involvement by COVID19 are rare though were described in an early population-based studies.

$\rightarrow$ Acute hemorrhagic encephalitis is a rare complication of viral illness, including COVID-19.

$\rightarrow$ The underlying mechanism in acute hemorrhagic encephalitis is poorly understood, but may be related to an autoimmune process.

$\rightarrow$ Intraparenchymal hemorrhage related to COVID-19 may be exacerbated by systemic anticoagulation.

$\rightarrow$ The initial neurologic presentation of COVID-19related hemorrhagic encephalitis is altered level of consciousness, which may prompt further neurologic examination and imaging to exclude this feature.

Appendix Authors

\begin{tabular}{lll}
\hline Author & Location & Contribution \\
\hline Alan Chalil, MD, MSc & $\begin{array}{l}\text { Department of Clinical } \\
\text { Neurological Sciences, } \\
\text { University Hospital, } \\
\text { London, ON, Canada }\end{array}$ & $\begin{array}{l}\text { Writing and editing the } \\
\text { initial manuscript and } \\
\text { revising the manuscript } \\
\text { (first and second rounds } \\
\text { of revision) }\end{array}$ \\
\hline Carmen S. Baker, MD & $\begin{array}{l}\text { Department of Physical } \\
\text { Medicine and } \\
\text { Rehabilitation, } \\
\text { University Hospital, } \\
\text { London, ON, Canada }\end{array}$ & $\begin{array}{l}\text { Writing and editing the } \\
\text { initial manuscript and } \\
\text { background/ } \\
\text { introduction review }\end{array}$ \\
\end{tabular}

Appendix (continued)

\begin{tabular}{lll}
\hline Author & Location & Contribution \\
\hline $\begin{array}{l}\text { Robert B. Johnston, } \\
\text { MD }\end{array}$ & $\begin{array}{l}\text { Department of Clinical } \\
\text { Neurological Sciences, } \\
\text { University Hospital, } \\
\text { London, ON, Canada }\end{array}$ & $\begin{array}{l}\text { Background/ } \\
\text { introduction review }\end{array}$ \\
\hline Caroline Just, MD, & $\begin{array}{ll}\text { Department of Clinical } \\
\text { Neurological Sciences, } \\
\text { University Hospital, } \\
\text { London, ON, Canada }\end{array}$ & $\begin{array}{l}\text { Researching } \\
\text { mechanism of } \\
\text { hemorrhage and } \\
\text { provided revisions and } \\
\text { responses to reviewers } \\
\text { in first round of }\end{array}$ \\
& & $\begin{array}{l}\text { revisions } \\
\end{array}$ \\
& &
\end{tabular}

Derek B. Debicki, MD, Department of Clinical Researching PhD, FRCPC Neurological Sciences, mechanism of University Hospital, hemorrhage and London, ON, Canada provided revisions and responses to reviewers in first round of revisions

Michael S. Mayich, Department of Medical Figures and radiologic MD, FRCPC Imaging, University interpretation of CT and Hospital, London, ON, MRI in the Discussion Canada section

\begin{tabular}{lll}
\hline $\begin{array}{l}\text { Karen J. Bosma, MD, } \\
\text { FRCPC }\end{array}$ & $\begin{array}{l}\text { Department of } \\
\text { Medicine, University } \\
\text { Hospital, London, ON, } \\
\text { Canada }\end{array}$ & $\begin{array}{l}\text { Editing and reviewing } \\
\text { the case presentation } \\
\text { and course in the } \\
\text { intensive care unit }\end{array}$ \\
\hline $\begin{array}{lll}\text { David A. Steven, MD, } \\
\text { MPH, FRCSC, FACS }\end{array}$ & $\begin{array}{l}\text { Department of Clinical } \\
\text { Neurological Sciences, } \\
\text { University Hospital, } \\
\text { London, ON, Canada }\end{array}$ & $\begin{array}{l}\text { Most responsible } \\
\text { physician; editing and } \\
\text { reviewing the initial } \\
\text { manuscript; editing and } \\
\text { reviewing the final }\end{array}$ \\
& $\begin{array}{l}\text { manuscript and } \\
\text { responses to reviewers' } \\
\text { comments; and } \\
\text { corresponding author } \\
\text { with the journal }\end{array}$ \\
& &
\end{tabular}

\section{References}

1. Shereen MA, Khan S, Kazmi A, Bashir N, Siddique R. COVID-19 infection: origin, transmission, and characteristics of human coronaviruses. J Adv Res 2020;24:91-98.

2. Stock JH, Aspelund KM, Droste M, Walker CD. Identification and Estimation of Undetected COVID-19 Cases Using Testing Data from Iceland. medRxiv 2020: 2020.2004.2006.20055582.

3. Wang D, Hu B, Hu C, et al. Clinical characteristics of 138 hospitalized patients with 2019 novel coronavirus-infected pneumonia in Wuhan, China. JAMA 2020;323:1061-1069.

4. Asia Filatrov PS, Hindi F, Patricio S. Espinosa neurological complications of coronavirus disease (COVID-19). Encephalopathy Cureus 2020;12:e7352.

5. Mao L, Jin H, Wang M, et al. Neurologic Manifestations of Hospitalized Patients With Coronavirus Disease 2019 in Wuhan, China. JAMA Neurol. 2020;77:683-690.

6. Poyiadji N, Shahin G, Noujaim D, Stone M, Patel S, Griffith B. COVID-19-associated acute hemorrhagic necrotizing encephalopathy: CT and MRI features. Radiology Epub 2020 Mar 31.

7. Gibbs WN, Kreidie MA, Kim RC, Hasso AN. Acute hemorrhagic leukoencephalitis: neuroimaging features and neuropathologic diagnosis. J Comput Assist Tomogr 2005;29:689-693.

8. Fugate JE, Lam EM, Rabinstein AA, Wijdicks EF. Acute hemorrhagic leukoencephalitis and hypoxic brain injury associated with H1N1 influenza. Arch Neurol 2010; 67:756-758.

9. Cisse FA, Antoine JC, Pillet S, Jousserand G, Reynaud-Salard M, Camdessanche JP. Acute hemorrhagic leukoencephalopathy associated with influenza A (H1N1) virus. J Neurol 2011;258:513-514.

10. Rosa Junior M, Borges EI, Fonseca APA, Fiorot JL, Balarini L, Valim V. Posterior reversible encephalopathy syndrome during treatment with tocilizumab in juvenile idiopathic arthritis. Arq Neuropsiquiatr 2018;76:720-721

11. Wu Y, Xu X, Chen Z, et al. Nervous system involvement after infection with COVID19 and other coronaviruses. Brain Behav Immun 2020;87:18-22.

12. Mehta P, McAuley DF, Brown M, et al. COVID-19: consider cytokine storm syndromes and immunosuppression. Lancet 2020;395:1033-1034.

13. Lann MA, Lovell MA, Kleinschmidt-DeMasters BK. Acute hemorrhagic leukoencephalitis: a critical entity for forensic pathologists to recognize. Am J Forensic Med Pathol 2010;31:7-11.

14. Jeganathan N, Fox M, Schneider J, Gurka D, Bleck T. Acute hemorrhagic leukoencephalopathy associated with influenza A (H1N1) virus. Neurocrit Care 2013;19:218-221. 


\section{Neurology ${ }^{\circ}$ Clinical Practice}

Acute Hemorrhagic Encephalitis Related to COVID-19

Alan Chalil, Carmen S. Baker, Robert B. Johnston, et al.

Neurol Clin Pract 2021;11; 147-e151 Published Online before print July 8, 2020

DOI 10.1212/CPJ.0000000000000900

This information is current as of July 8, 2020

\begin{tabular}{|c|c|}
\hline $\begin{array}{l}\text { Updated Information \& } \\
\text { Services }\end{array}$ & $\begin{array}{l}\text { including high resolution figures, can be found at: } \\
\text { http://cp.neurology.org/content/11/2/e147.full.html }\end{array}$ \\
\hline References & $\begin{array}{l}\text { This article cites } 12 \text { articles, } 0 \text { of which you can access for free at: } \\
\text { http://cp.neurology.org/content/11/2/e147.full.html\#\#ref-list-1 }\end{array}$ \\
\hline Subspecialty Collections & $\begin{array}{l}\text { This article, along with others on similar topics, appears in the } \\
\text { following collection(s): } \\
\text { COVID-19 } \\
\text { http://cp.neurology.org//cgi/collection/covid_19 } \\
\text { Critical care } \\
\text { http://cp.neurology.org//cgi/collection/critical_care } \\
\text { CT } \\
\text { http://cp.neurology.org//cgi/collection/ct } \\
\text { Encephalitis } \\
\text { http://cp.neurology.org//cgi/collection/encephalitis } \\
\text { Intracerebral hemorrhage } \\
\text { http://cp.neurology.org//cgi/collection/intracerebral_hemorrhage }\end{array}$ \\
\hline Permissions \& Licensing & $\begin{array}{l}\text { Information about reproducing this article in parts (figures,tables) or in } \\
\text { its entirety can be found online at: } \\
\text { http://cp.neurology.org/misc/about.xhtml\#permissions }\end{array}$ \\
\hline Reprints & $\begin{array}{l}\text { Information about ordering reprints can be found online: } \\
\text { http://cp.neurology.org/misc/addir.xhtml\#reprintsus }\end{array}$ \\
\hline
\end{tabular}

Neurol Clin Pract is an official journal of the American Academy of Neurology. Published continuously since 2011, it is now a bimonthly with 6 issues per year. Copyright (c) 2020 American Academy of Neurology. All rights reserved. Print ISSN: 2163-0402. Online ISSN: 2163-0933.

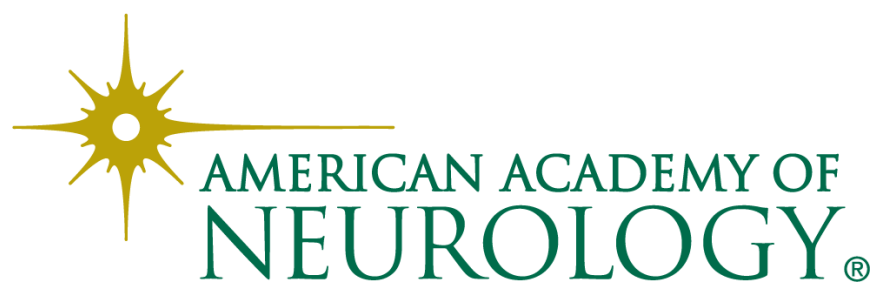

